\title{
Die volkskerkvoorstelling in die Kerkwet van die Nederduitsch Hervormde Kerk van Afrika
}

\author{
JH Koekemoer
}

\begin{abstract}
The term Volkskerk in the Church Order of the Nederduitsch Hervormde Kerk van Afrika

The Nederduitsch Hervormde Kerk states in its Church Order that it is a volkskerk (people's church). In this article the term volkskerk and the historical line of how it came to use in the Nederduitsch Hervormde Kerk, is researched. In the light of these statements the term volkskerk and its meaning in the contemporary Order of the Nederduitsch Hervormde Kerk, is dealt with.
\end{abstract}

\section{INLEIDING}

In die finale instansie sal dit nodig wees om ons by die huidige Kerkwet van die Nederduitsch Hervormde Kerk van Afrika te bepaal ten einde vas te stel hoe die volkskerkvoorstelling daarin na vore tree.

Voordat daarby gekom kan word, moet daar egter aan twee sake kortliks aandag gegee word:

Eerstens moet daar na die wese, aard, karakter en opdrag van die kerk as volkskerk gekyk word. Dit is nodig om te kan bepaal of die term volkskerk nie die wese en grense van die kerk oorspan nie.

Hierna sal aandag gegee moet word aan die historiese agtergrond waarteen die huidige Kerkwet sy beslag gekry het. So alleen sal op 'n sinvolle wyse bepaal kan word of en hoe die volkskerkvoorstelling in die Kerkwet van die Nederduitsch Hervormde Kerk van Afrika funksioneer.

\section{DIE KERK AS VOLKSKERK}

'n Mens sou moes begin deur te stel dat kerk en volk nooit met mekaar gelykgestel kan word nie. Alhoewel God albei tot stand gebring het, is 
hulle ten ene male nie identies nie. Daarom kan die grense van die kerk ook nooit gelykgestel word aan die grense van die volk nie. Indien so 'n gelykstelling plaasvind, sou dit nie alleen die wese van die kerk in gedrang bring nie, maar dit sou tegelyk ook'n vraagteken plaas oor die werk van die Heilige Gees en die eie geloofsbeslissing van lidmate van die kerk. Mense behoort eenmaal nie vanselfsprekend tot die kerk van Jesus Christus nie. Ten opsigte van lidmaatskap van die kerk is daar altyd ook sprake van uitverkiesing, verbond en belydenis van geloof. Hierdie spanning tussen God wat handel, God wat roep en die mens wat in geloofsverantwoordelikheid hierop moet antwoord, kan eenvoudig nie genegeer of opgehef word nie. Die uitverkiesing van God word tog weerspieël en verwerklik in die keuse van 'n mens. Aan die ander kant is dit ook weer waar dat hierdie nuwe vryheid van die mens om so te kan kies uiteindelik ook deur God bewerk word, maar dit bly tog die mens wat kies om te bely. Op dié wyse het hy deel aan die heil wat God skenk (Van Ruler 1958).

Wanneer enige mens egter so 'n belydenis uitspreek, is hy nie 'n losstaande individu nie. Daar is altyd sprake daarvan dat hy ' $n$ medewerker van God is en 'n deelnemer aan die volk van God. Hy is deel van God se volk en so kry hy deel aan die heil wat God skenk. Hoe kan dit ook anders. Wie immers 'verbond' sê, sê 'gemeenskap'. In die gemeenskap word enkelinge tegelyk met God en met ander mense verbind (Berkhof 1973: 356). Hierdie geloofsgemeenskap wat so tot stand kom, die kerk, adem op grond van sy wese en ook die wyse waarop mens daarvan deel word, ' $n$ totaal ander gees as enige ander gemeenskap op aarde. Dit is anders as familie, volk en kultuurgemeenskap.

'n Mens sou ook kon sê daar is 'n bepaalde vreemdheid ten opsigte van ander gemeenskappe daaraan verbonde.

Dit wil egter nie sê dat daar nie 'n plek vir hierdie ander gemeenskappe bestaan nie. God het immers ook gewil dat daar sulke ander gemeenskappe soos onder andere volke in die wêreld sal bestaan. Ons word immers almal gebore binne die kring van sulke gemeenskappe. Ons aanskou die lewenslig binne ' $n$ gesin wat op sy beurt aan ' $n$ bepaalde familie behoort en verder uitkring na ' $n$ bepaalde volk toe.

Die wonder van God se genade kom nou juis hierin na vore en vat ook grond binne die werklikheid van ons bestaan. Terwyl ons deel word van die kerk hou ons nie op om lid te wees van die ander gemeenskappe waarin ons gebore is nie. In hierdie spanningsveld wat so tot stand kom, kan ons met vreugde leef tot eer van God. 'n Mens sou 
ook kon sê dat hier uiteindelik, soos mense binne kultuurpatrone lidmate van die kerk word sonder om op te hou om hulle verbande op te sê, sprake kom van die verbinding tussen volk en kerk. Hier sou gepraat kon word van volkskerk. Maar dan sal 'n paar sake in gedagte gehou moet word.

'n Mens sal gedurig bedag moet wees op die spanning wat hierdie verbinding na vore bring. Jy sal die 'vreemdheid' van die kerk teenoor en in verhouding tot die volk nie mag vergeet nie.

Die grense van die volk is nie tegelyk die grense van die kerk nie. Die kerk is kerk van Jesus Christus. Hy is die hoof daarvan en dit is sy liggaam wat in die wêreld deur Hom geroep, onderhou en gebruik word om sy werk te doen.

Verder sal daar ook in gedagte gehou moet word dat daar van die gelowiges, die kerk, gesê word dat hulle vreemdelinge en bywoners in die wêreld is. In diê opsig sal die vraag beantwoord moet word tot hoe 'n mate daar van vreemdelinge en bywoners sprake kan wees (Van Ruler 1958). In die lig van wat reeds gestel is, sou ons ook moet stel dat, alhoewel die kerk vreemd vir die wêreld is, die wêreld nooit vreemd vir die kerk kan wees nie. Die kerk sou ook die wêreld en daarmee saam die volk(e) waaruit sy lidmate kom, moet bekyk. Dit maak dit juis so noodsaaklik dat ons van 'n volkskerk kan praat (Van Ruler 1958) sonder om bang te wees vir die spanningsveld wat in hierdie verbinding na vore geroep word. Ons bly immers in die wêreld, alhoewel ons nie van die wêreld is nie. Die kerk kan hom nie uit die wêreld onttrek nie; hy het nie alleen ' $n$ boodskap van redding wat hy in die wêreld uitdra nie, maar hy het ook teologiese en kerklike kritiek te lewer. En omdat sy lede ook lede van ander gemeenskappe is (o a van 'n volk), bring dit noodwendig mee dat hy die volkslewe en die sake van die volkslewe sal verstaan.

Van kop tot tone is volkskerk die kerk van die Bybel. Ten voete is dit die liggaam van Christus. Sy oë sien die volk raak, sy ore hoor die volkstaal, sy mond spreek die moedertaal, sy hande handel op die volksterreine, sy voete bewandel die vaderland van sy volk, sy hart ken die vrese en liefdes, die swakheid en roem, die eersug en lafhartigheid van sy volk. Daarom kan hy die gedagtes uit die brein of die Woord van Sy Hoof met sensitiwiteit (Rom 12: 2, Fil $1: 9,10$ ), doelgerigtheid en klarigheid spreek (Van der Westhuizen 1986: 13).

'n Mens sou dit ook anders kon sê: Die kerk, wat so volkskerk is, het die 
verantwoordelikheid om die volkslewe te verstaan, te beleef en te orden met die kennis wat hy uit die Woord van God daarvan opgedoen het.

Dit is juis om hierdie rede dat daar in die Teologie ook ruimte moet wees vir groothede soos familie, kultuur en volk (Van Ruler 1958). Daar is ten opsigte van die volkskerk nog 'n ander aspek wat ook nie uit die oog verloor mag word nie. Hierdie saak lê binne die apostolaat van die kerk.

As in hierdie verband die gerigtheid van die volkskerk ook die volk is, verkondig hy die evangelie met die bedoeling om soveel moontlik lede van die volk in sy gemeenskap op te neem.

Terwyl hy dit doen, sal hy tegelyk ook moet onthou dat hy nie die pleitbesorger van 'n bepaalde volk kan wees nie, maar in die taal wat hy praat, apostel vir alle mense moet wees. In die apostoliese aktiwiteit is die kerk egter nie alleen besig met alle mense nie, maar ook met die hele samelewing, en met alle momente van die lewe van alle mense. Om daardie lewe en al sy momente gaan dit immers vir die kerk. (Oberholzer 1985). Anders gestel: Wanneer die kerk met die evangelie die wêreld ingaan, beleef hy die werklikheid so dat daar verskillende volke in eie kultuurpatrone lewe. Die feit dat hy as apostel van Jesus Christus in die wêreld wil leef, kan dan beteken dat hy in sulke lewensverbande kerstenend en evangeliserend wil inbeweeg. Hy sal natuurlik altyd oproep tot bekering en geloof en so die geloofsverbondenheid aan Jesus Christus voorop stel, maar hy sal aan die ander kant mense nie wil losruk uit hulle lewensverbande nie. Hy sal eerder 'n ander kwaliteit daaraan wil toeken. Sy verantwoordelikheid teenoor die Here beteken vir hom dat hy met vrymoedigheid in die kultuurgestalte wat ook hy aangeneem het en in die taal wat hy praat, apostel vir alle mense kan wees (Oberholzer 1985).

Soos aan die begin gestel is, mag die kerk dus nooit op so ' $n$ wyse een met die volk word dat sy verbondenheid aan sy Heer in gedrang kom nie. Omdat sy verbondenheid aan sy Heer vir hom van soveel wesenlike belang is, moet hy altyd 'n gestalte van die een, heilige, algemene, Christelike Kerk wees.

Dit beteken dat die wesenskenmerke van die kerk altyd sonder meer op die volkskerk van toepassing moet wees. As die Nederduitsch Hervormde Kerk van Afrika dus volkskerk wil wees, sal hy kerk vir die volk kan wees, maar nooit kerk van die volk kan wees in die sin dat hy aan 'n volk behoort nie. Dit is eenvoudig so omdat die grense van die volkskerk nie die volk van die volkskerk is nie, maar die kerk van die volkskerk (Van der Westhuizen 1986). 'n Volkskerk sal altyd kerk van 
die Here moet wees wat die evangelie ook aan 'n bepaalde volk moet verkondig. Hy sal in die ganse lewe van die volk kerstenend moet inbeweeg maar hom nooit so met die volk kan identifiseer dat hy sy kritiese ingesteldheid op die lewe van die volk sal verloor nie. Hy sal moet on thou dat hy sy heil nie van 'n bepaalde volk nie, maar alleen van Jesus Christus kan verwag.

Die feit dat die kerk dit weet en ook op dié wyse aan die Woord diensbaar wil wees, beteken nie dat wanneer mense lidmate van die kerk word, hulle ophou om lede van 'n volk te wees nie. Dit beteken alleen dat hulle binne hulle lewensverbande hulle verantwoordelikheid nog beter kan nakom.

Wanneer die apostolaat van die kerk verder ter sprake kom, kom die volkskerk se apostolêre verantwoordelikheid teenoor ander volke ook in die gesigsveld. Omdat die volkskerk ook in die eerste plek kerk van die Woord is, beteken dit dat hy ook hierdie taak met ywer en met blymoedigheid moet verrig. Om hierdie rede kan sy taak dus nooit ophou binne die grense van net een volk en een taal nie. Die evangelie moet immers verkondig word tot by die eindes van die wêreld. Wat hierdie aspek van die apostolaat betref, sal dit beteken dat die kerk hom moet rig tot ander volke en gemeenskappe met die gedagte dat ook daar volkskerke gevorm sal word, sodat die Here in wie se diens die kerk staan, gedien kan word.

\section{KORT HISTORIESE OORSIG}

In 'n artikel het Pont (1986) die historiese lyn ten opsigte van die begrip 'volkskerk' noukeurig nagegaan en ook duidelik gestel wat dit in die konteks wil sê. Verder kan daarop gewys word dat Botha (1973) ook ten opsigte van die oorsprong van die begrip en sy funksionering binne die Nederduitsch Hervormde Kerk van Afrika duidelike sake aan die orde gestel het. Verder het hy in 'n memorandum aan die Algemene Kommissie in 1986 weer op die saak teruggekom. Ter wille van die feit dat vir hierdie artikel hierdie saak van belang is, word hierna verwys en enkele van die gedagtes in genoemde stukke kortliks hier weergegee. Aangesien daar nie hier na die situasie in Nederland teruggegaan word nie, en daar ook net in die verbygaan na die kerkgeskiedenis van die vorige eeu verwys word, sal dit goed wees om die artikels te bestudeer om 'n breër beeld van die saak te verkry.

Uit sy geskiedenis is dit duidelik dat die Nederduitsch Hervormde Kerk van Afrika die volkskerkgedagte onderskryf. 
Die Nederduitsch Hervormde Kerk van Afrika is kragtens sy geskiedenis Christus-Belydende volkskerk en wil dit ook uit beginsel wees (Botha 1986).

Natuurlik gaan hierdie saak terug na sy herkoms uit Nederland (Pont 1986) en selfs na sy verstaan van die gebeurtenisse rondom die kerkhervorming (Botha 1973; 1986; Pont 1986).

Reeds vroeg in sy geskiedenis van die vorige eeu is dit aan te dui dat daar in die Nederduitsch Hervormde Kerk 'n noue verbondenheid tussen kerk en volk bestaan het, alhoewel dit duidelik gestel moet word dat dit nie 'n wesensverband was nie. Dit was steeds die bedoeling van die kerk om die evangelie die bepalende invloed te laat uitoefen op alle samelewingsverbande.

Botha (1986: 15) stel dit dat die begrip 'nationale volkskerk' deur ds MJ Goddefroy in die Nederduitsch Hervormde Kerk in gebruik gekom het. Hy word tegelyk ook aangedui as die persoon wat die wegbereider was wat gesorg het dat Hoedemaker en sy navolgers se denke oor 'n Christus-belydende volkskerk in die Nederduitsch Hervormde Kerk van Afrika 'n pad kon vind.

Hierdie soort volkskerk is die een:

wat so onder die volk arbei dat, indien moontlik, die hele volk tot die kerk van Jesus Christus toegebring word, maar dan deur die middele en op die wyse wat deur God verorden is. Dit beteken dus dat die volkskerk, ' $n$ kerk is wat nie tevrede kan wees daarmee dat daar lede van die volk of lewensterreine van die volkshuishouding kan wees wat nie na die eise van Gods Woord wil luister nie. Daarom is die volkskerk daarop ingestel om voortdurend, sonder ophou, elke lid van die volk en elke lewensterrein te konfronteer met die evangelie en te probeer kersten tot eer van God (Botha 1973: 41).

Hierdie gedagtes van Hoedemaker het in Nederland ook hulle neerslag gevind onder andere in die Kerkwet van 1950-51 van die Nederlandse Hervormde Kerk.

Pont wys daarop dat die reorganisasie van die Nederduitsch Hervormde Kerk na 1885 eers behoorlik aan die gang gekom het nadat ds MJ Goddefroy in 1887 as predikant van die gemeentes Pretoria (Witfontein), Middelburg en Trichardtsfontein bevestig is. Op die Algemene Kerkvergadering van 1888 is daar dan ook beklemtoon dat die Nederduitsch Hervormde Kerk sy taak bly sien om die evangelie te 
verkondig en ook sy rol op die staatkundig-kulturele vlak te speel as 'de nationale volkskerk'.

Pont (1969) wys verder daarop dat uit die Broederlijks schrijven van 1888 afgelei kan word dat die Algemene Kerkvergadering ondanks veranderde omstandighede die Nederduitsch Hervormde Kerk beskou het as die voortsetting van 'de nationale volkskerk'. Hierdie kerk het behalwe sy taak tot evangelieverkondiging ook op die staatkundigkulturele vlak' $n$ opdrag gehad. Hoewel die kerk nie meer die hele volk van die $Z$ A Republiek omvat het nie, het dit tog sy taak gesien as 'nationale volkskerk'.

Die Algemene Kerkvergadering van 1888 formuleer, al is dit baie kortliks, die gedagte van die volkskerk wat die gevolg daarvan was dat die Kerk met sy Evangelieprediking en sakramentsbediening volkome ingegaan het in die organiese geledinge van die volk en daarom ook ' $n$ bepalende invloed uitgeoefen het op die staatkunde, die maatskaplike en openbare lewe. Die kerk was feitlik die verbesondering van die godsdiens wat elke dag uitgeleef is. Die kerk was die liggaam wat die volk as geheel opgeroep het en wou lei om 'n heilige gemeenskap te wees wat alleen tot eer van God geleef het. Daarom het die Kerk en kon die Kerk ook nie losstaan van die staatkundige en maatskaplike en kulturele lewe van die volk nie, maar het die Kerk ook daar die rigtinggewende Woord van God uitgedra (Pont 1969).

\section{DIE HUIDIGE KERKWET VAN DIE NEDERDUITSCH HERVORMDE KERK VAN AFRIKA}

Na hierdie enkele gedagtes oor wat 'n volkskerk is en hoe dit in die Nederduitsch Hervormde Kerk van Afrika sy pad gevind het, sal dit goed wees om na die huidige situasie binne die Nederduitsch Hervormde Kerk ten opsigte van die saak te kyk. Daar sal gepoog word om na te gaan of bogenoemde gedagtes wel hulle neerslag in die Kerkwet van die Nederduitsch Hervormde Kerk gevind en behou het.

Vooraf moet gestel word dat van die drie Afrikaanse kerke die Nederduitsch Hervormde Kerk die enigste is wat uitdruklik die volkskerkgedagte aanvaar. Dit het ook weer tydens die besprekings op die Algemene Kerkvergadering van 1986 duidelik na vore getree.

Wanneer sulke uitsprake gehoor word, sou die eerste vraag natuurlik wees wat die Kerk huidig onder die begrip volkskerk verstaan? Een 
wyse om dit te probeer peil, is om in die lig van wat ons reeds gesê het, te kyk na die huidige Kerkwet van die Nederduitsch Hervormde Kerk van Afrika.

In artikel I van sy Kerkwet stel die Nederduitsch Hervormde Kerk dat hy hom grond op die Bybel as die Woord van God. Dit kan eintlik ook nie anders nie, want die kerk is altyd en alleen kerk van die Woord. Die kerk is geroepe om die Woord van God te verkondig en op dié wyse mense op te roep tot bekering en geloof. Tegelyk sê die Nederduitsch Hervormde Kerk in genoemde artikel egter dat hy ooreenkomstig sy belydenis, openbaring van die een heilige, algemene Christelike kerk is. Daarmee het die Kerk die volgende gesê: Daar is maar een kerk van Jesus Christus en hierdie kerk is heilig en algemeen. Die eenheid van die kerk tree hierin sterk na vore, maar tegelyk ook die heiligheid en die algemeenheid. Die Nederduitsch Hervormde Kerk bely nou dat hy 'n gestalte van die een, heilige, algemene Christelike kerk is.

Hiermee het hy nie gesê dat hy die enigste gestalte is nie, maar tog ondubbelsinnig gesê dat hy 'n gestalte is. In sy lewe en werk sê hy dus dat hy kerk van Jesus Christus wil wees en getrou aan die een Heer, sy roeping en verantwoordelikheid wil uitvoer. Wanneer hy dan verkies om as volkskerk, kerk te wees, moet dit wat in artikel I van sy Kerkwet gestel word, steeds in gedagte gehou word. Die Nederduitsch Hervormde Kerk maak immers die keuse onder die besef dat kerk en volk nie identies is nie en dat die kerk nooit in die volk kan opgaan nie. Daarom wil hy die spanning tussen kerk en volk steeds handhaaf (vgl hieroor punt 2 van hierdie artikel).

Dit is veral in die motivering van Artikel III van sy Kerkwet dat die volkskerkgedagte die duidelikste na vore tree.

Die kerk, bewus van die gevare wat vermenging van Blank en nie-Blank vir altwee groepe inhou, wil geen vermenging in sy midde toelaat, maar beoog die vorming van ander volkskerke onder die verskillende volksgroepe, in die oortuiging dat aldus die bevel van die Here - 'Gaan dan na al die nasies toe en maak die mense my dissipels' (Matt 28: 19) - die beste tot sy reg sal kom en dat die eenheid in Christus deur so 'n werkverdeling nie geskaad sal word nie (Kerkwet 1986).

Alhoewel die bedoeling van die artikel in die Suid-Afrikaanse situasie duidelik behoort te wees en seker ook vir die meeste lidmate van die kerk duidelik is, moet erken word dat die begrippe ras en volk hier op 
so 'n wyse vermeng word dat kritici dit aanwend om 'n beskuldiging van rassisme na vore te bring.

- Omdat die kerk, kerk wil wees op die wyse van 'n volkskerk en nie rassisme wil preek nie, is dit seker nodig dat hy hier in sy getuienis duidelik en wetenskaplik meer korrek oor homself moet getuig.

Soos wat Artikel III egter op die oomblik daar staan, is dit onwetenskaplik bewoord en maak dit die beskuldiging van rassisme maklik (Van Wyk 1985).

Dat die kerk erns met die saak maak, is te vind in die feit dat verskillende ondersoekkommissies reeds daarna gekyk het en dat die Algemene Kerkvergadering van 1986 opnuut 'n Kommissie benoem het om die kerk van die nodige advies oor hierdie aangeleentheid te bedien.

'n Moontlike oplossing sou kon wees om die volkskerkgedagte meer eksplisiet in Artikel I uit te spel, Artikel III te laat as 'n gewone lidmaatskapartikel en in Artikel IX oor die apostolaat te handel waar dit in elk geval aan die orde kom. In dié verband sou ' $n$ moontlike formulering van Artikel I dan soos volg kon lees:

Die Nederduitsch Hervormde Kerk van Afrika grond hom op die Bybel as die Woord van God. Ooreenkomstig sy belydenis is die Kerk openbaring van die een heilige, algemene Christelike Kerk, en wel in die gestalte van 'n volkskerk....

Prof dr FJ van Zyl het dan ook op die Algemene Kerkvergadering van 1986 argumente in diê rigting aangevoer en ' $n$ voorstel in dié verband ingedien.

Die Kerk as volkskerk sal egter steeds sy apostolêre verantwoordelikheid teenoor alle volke moet nakom. Hy bly immers in die eerste plek kerk van die Woord. Die evangelie moet immers voortgedra word tot by die eindes van die wêreld. Wat die apostolaat betref, beteken die volkskerkgedagte dat die kerk hom rig tot ander volke met die gedagte om ook daar volkskerke te vorm.

Die Kerk rig hom in die sending tot bevolkingsgroepe of gemeenskappe in Afrika, wat nog heidens of gedeeltelik heidens is om hulle te help met die verspreiding van die evangelie in hulle eie gemeenskapslewe en deur diegene wat daar tot geloof gekom het, by te staan by die inrigting en opbou van 'n eie kerklike lewe sodat hulle uiteindelik tot afsonderlike selfstandige kerk(e) kom (Kerkwet, Artikel IX), 
Omdat die Kerk as volkskerk ook die verantwoordelikheid het om die volkslewe te verstaan, te beleef en te orden met die kennis wat hy uit die Woord van God daarvan opgedoen het, kan die Nederduitsch Hervormde Kerk dit ook duidelik in sy Kerkwet sê. Hier stel hy dat die opdrag van Christus aan sy kerk is om onder andere teenoor owerheid en volk te getuig en ook om medeverantwoordelik te wees vir die Christelike opvoeding van die kinders van die Kerk en volk (Kerkwet, Artikel IV).

Verder ook nog:

Kragtens sy roeping om die lewens volgens die behoeftes en die wil van God in te rig, is die Kerk mede-verantwoordelik vir die opvoeding van en die onderwys aan die jeug van die hele volk in 'n Christelik-nasionale gees, in huisgesin en skool (Kerkwet, Artikel X).

As ons sê dat die Kerk nie alleen besig is met alle mense nie, maar ook met die hele samelewing en alle momente van die samelewing en dat die volkskerk dit by uitnemendheid wil doen, dan kan ons nie anders as om te konkludeer dat die Nederduitsch Hervormde Kerk ook hier iets van sy kerkwees in die wêreld tot uitdrukking wil bring nie.

'n Volkskerk is vanweë sy grense, opdrag en gerigtheid nie imperialisties, bowenasionaal, antinasionaal of internasionaal nie. $\mathrm{Hy}$ is intranasionaal en wil die volk in al sy geledinge kersten tot 'n Christelik-nasionale bestaan (Van der Westhuizen 1986).

Daar bly nog een vraag oor wat ook ten opsigte van die volkskerkvoorstelling in die Nederduitsch Hervormde Kerk beantwoord behoort te word. Hierdie vraag en antwoord is ten opsigte van die volkskerk in die algemeen deur Van der Westhuizen (1986) soos volg geformuleer:

Beoog die volkskerk nie maar dieselfde as die moderne genitiefsteologieë nie? As gemeenskapsteologieë konsentreer hulle tog ook op die eiesoortigheid van 'n besondere gemeenskap se behoeftes.

Die antwoord op die vraag is: Nee, indien daar iets gemeenskapliks is in wat die volkskerk en die gemeenskapsteologieë beoog, is daar nogtans 'n hemelsbreë verskil in hulle selfbeeld wat deur die onderskeie taakerkenning gevorm word. Die gerigtheid van 'n volkskerk, naamlik die volk, mag nooit sy taak, naamlik die Woord van God, word nie. Dit is die verskil met die gemeenskapsteologieë, dat hulle gerigtheid meteens ook hulle taak is. 
Uit die Kerkwet van die Nederduitsch Hervormde Kerk word dit gou duidelik dat sy taak en gerigtheid nie identies is nie. Hoe sterk hy ook al kulturele gestalte wil aanneem, wil hy nie daarmee in volk en kultuur opgaan nie. Die Nederduitsch Hervormde Kerk van Afrika wil steeds aan die Woord diensbaar wees (Kerkwet, Artikel IV) en hy wil steeds ooreenkomstig sy belydenis openbaring van die een heilige, algemene Christelike kerk wees. Juis daarin, dat hy universele kerk bly, kan hy ook volkskerk wees (Oberholzer 1985).

Dit bly seker waar dat daar ook in die Kerk se siening van homself en in sy formulering van sy kerkwees in die wêreld gebreke en tekortkominge voorkom. Maar aan die ander kant wil hy as reformatoriese kerk dit steeds in die lig van die Woord van God reformeer, en wil hy die spanningsveld tussen kerk en volk steeds krities evalueer. Daarom kan hy ook met reg verklaar:

In dankbare gehoorsaamheid aan die Woord van God wat deur die werking van die Heilige Gees bron van enigste inhoud van die prediking en reël van die geloof is, bely die hele Kerk in gemeenskap met die vadere, in die besef van sy verantwoordelikheid vir die hede en in verwagting van die toekoms van die Here Jesus Christus, sy geloof in die Drie-enige God (Kerkwet, Artikel XI).

Dit is in hierdie geloof, in gehoorsaamheid aan die Woord van God wat die Kerk sy taak wil uitvoer. Natuurlik sal hy steeds bedag daarop moet wees om, terwyl hy in die wêreld is, nooit van die wêreld te word nie. Hy sal terwyl hy volkskerk is nooit so een met die volk kan word dat hy sy kritiese ingesteldheid teenoor die volk verloor nie. Die oplossing lê nie daarin om hom uit die wêreld en uit die volk te onttrek nie, maar om in die taal wat hy praat en in die kultuurgestalte wat hy aạngeneem het, apostel van Jesus Christus te wees. In hierdie spanningsveld leef en werk hy. Dit is tegelyk sy roeping en sy vreugde. So wil die Nederduitsch Hervormde Kerk kerk wees.

\section{Literatuurverwysings}

BERKHOF, H 1973. Christelijk geloof. Nijkerk: Callenbach.

BOTHA, SJ 1973. Die volkskerk. Pretoria: HAUM.

BOTHA, Sj 1986. Die volkskerk. Ongepubliseerde memorandum voorgelê aan die Kommissie van die Algemene Kerkvergadering van die Nederduitsch Hervormde Kerk van Afrika.

KERKWET EN BEPALINGS VAN DIE NEDERDUITSCH HERVORMDE KERK VAN AFRIKA 1986. Pretoria: NHW-Pers. 
OBERHOLZER, JP 1985. Die taak van die Kerk teenoor die owerheid. HTS 41, 14-28.

PONT, AD [1969]. Kerk en volk. HTS 25/ 3 en 4, 202-218.

PONT, AD 1986. Verbond en volkskerk. HTS 42, 28-76.

VAN DER WESTHUIZEN, HG 1986. Volkskerk as normale kerkbeskouing. Ongepubliseerde memorandum voorgelê aan die Kommissie van die Algemene Kerkvergadering van die Nederduitsch Hervormde Kerk van Afrika.

VAN RULER, AA 1958. Heeft het nog zin, van volkskerk te spreken? Wageningen.

VAN WYK, DJC 1985. Artikel III van die Kerkwet van die Nederduitsch Hervormde Kerk van Afrika: 'n Verantwoording. Pretoria: Kital. 